\title{
UTILIZING ALPHABETICAL CARDS IN IMPROVING EFL STUDENTS' VOCABULARY
}

\author{
Derin Karbala \\ derinkarbala@gmail.com
}

\begin{abstract}
The research aims at improving EFL students' vocabulary through Alphabetical Cards. The subject of this classroom action research was 40 students. The research was a classroom action research which was conducted in two cycles where each cycle consisted of planning, implementation, observation and reflection. The data of this research were obtained from the results of the test and observation sheet, questionnaire, field notes, during the implementation of the action. The findings of the research showed that Alphabetical Cards was effective in improving EFL students' vocabulary. The effectiveness of Alphabetical Cards was shown by the improvement of students' score. The findings revealed that in cycle 1 there were 18 students who achieved minimum criteria of achievement. It means that the classical achievement was $45 \%$. In cycle 2 , it showed that there were 36 of 40 students who achieved the minimum criteria of achievement. It means that the gain achievement was $90 \%$. Gain achievement is based on the number of students who get the score at least the criteria of success (70). Both of the gained and individual achievements have met the criteria of success. It can be concluded that the alphabetical cards is very effective to improve the students' vocabulary.

Keywords: Vocabulary, Alphabetical Cards, EFL students
\end{abstract}

\section{INTRODUCTION}

Language is a tool of communication for human being because language is used in daily activities. It is used to express ideas, feeling, and thought. However, in order to make someone able to acquire a language especially foreign language, someone must learn the language (Burden and Byrd, 1995; Harmer , 1998; Albana et al., 2020; Alek et al., 2020; Kuliahana and Marzuki, 2020).

To make students able to communicate in a language, they must master the vocabulary of the language. Vocabulary is very important in language learning and it must be learned by students. It is the basis of the language, not only in English but also in other languages. Vocabulary mastery of the students is able to assist them to communicate by using this language (Nation, 1990; Richards, 2001; Rolando, 2003; Marzuki, 2019). 
In teaching and learning activities for school students, some teaching media can be used: such as song, games, puzzle-word, pictures, word list of card, and alphabetical card. These media can help the teacher to teach students to master the English vocabulary (Marzuki et al., 2018; Marzuki, 2019a). Many students have low ability in vocabulary especially for school students. Even though, they have already studied English in Elementary School level. The students got difficult to remember the vocabulary (Marzuki, 2017; Marzuki, 2019c). The lack of vocabulary may derive from both students as the learners and the teacher as the instructor. Students' inability in memorizing a number of words make them difficult to learn English. While teacher's inability to choose a good technique make the teacher difficult to explain material for students. Therefore students need one technique to increase their vocabulary like alphabetical cards.

The researcher used alphabetical cards technique in teaching English vocabulary because alphabetical card is a simple technique. It can be a first step in learning English vocabulary, because the English teacher can decide the number of words use by the students. Alphabetical cards are aimed to help the student and remember new words of English. It is used to introduce the students to English words.

The researcher conducted a research by using alphabetical cards to the students. She stimulated the students' intention and desire to develop their knowledge and skill in English. She got easy to teach the students in understanding the word given.

Based on the above statement, the researcher conducted a research dealing with teaching vocabulary to the students through alphabetical cards. Researcher chose this topic because using alphabetical cards technique could help the students memorize words.

The researcher chose the research sample because she found that the students got difficult to remember the vocabulary. The lack of vocabulary may derive from both students as the learners and the teacher as the instructor. Students' inability in memorizing a number of words make them difficult to learn English. While teacher's inability to choose a good technique make the teacher difficult to explain 
material for students. Based on the problem statement, the researcher made it more precise on the target of description, the researcher formulated in research question as follow:

How effective is Alphabetical Cards in Teaching Vocabulary to the EFL students?

\section{RESEARCH METHOD}

The design of this research was CAR (Classroom Action Research). The research was focused on particular classroom or group with qualitative and quantitative approach. This classroom action research was designed to increase students' vocabulary. The technique was developed into more applicable model through spiral of cycle; each of which covered planning, acting, data collecting, analyzing and reflecting.

According to Kemmis and Taggart, Classroom Action Research suggests the researcher to have a collaborative action. Action research is collaborative; it involves those responsible in improving it, widening the collaborating group from those most directly improved to as many as possible of those affected by the practice concerned (Kemmis and McTaggart, 1988; McNiff, 1992; Wallace, 1998; Nunan, 1998; Richard and Renandya, 2002; Marzuki, 2016). This research required the researcher and her collaborator design lesson plans, prepare instructional material and media, and implement the action plan.

This research was conducted at one school in Indonesia. Each of the grades (the first up to the third year) had parallel classes, where the students spread out randomly.

\section{The Steps of Research}

To conduct the research, the researcher and her collaborator began the research from planning, implementing, observing, and reflecting. The four main activities were called stages.

Here is the scheme of action research:

Figure 3.1 Classroom Action Research Scheme

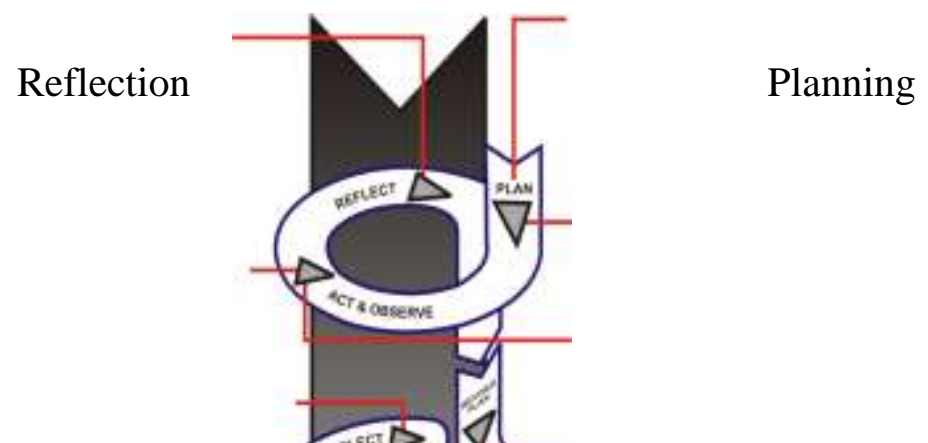




\section{Implementation}

\section{Observation}

(Adapted from Kemmis and

Stop

Taggart's in Nunan, 1998: 13)

1. Planning

The first activity was done by the researcher and her collaborator in this research was that to do the planning. The researcher and her collaborator worked collaboratively to design lesson plan, prepared instructional material and media, and to construct the criteria of success. The steps of planning were done on the basis on the technique. The planning was also focused on designing learning environment in which the students got involve in teaching vocabulary through alphabetical cards.

a. Designing Lesson Plan

The researcher and her collaborator designed lesson plan related to the teaching of vocabulary. Lesson plans were designed to teach vocabulary through alphabetical cards.

The general plan substances were as follows:

1. Researcher determined teaching strategies, theme and teaching and learning items, objectives of teaching and learning, way of grouping students, activities of teachers and students in teaching and learning process, material and media used, and evaluation/assessment process and its result. 
2. Researcher and her collaborator together designed observation guide lines made teacher and students' activities formats during teaching and learning process, prepare field notes, and achievement criteria.

b. Preparing Instructional Matrials and Media

The researcher and her collaborator prepared the material required in the teaching learning process. In order to achieve effective classroom management in classroom activities.

\section{c. Criteria of Success}

In order to have required achievement in vocabulary and to determine continuation of cycle, criteria of success need to be previously determined. Therefore, the researcher and the collaborator determined the criteria of success as follows: The students' score should achieve 70 (based on minimal completing criteria) and there should be at least $70 \%$ students who get individual achievement at least 70 (this is taken from achievement test).

1. The students can learn cooperatively in small group or pairs to share their opinion, ideas, argumentation, understanding, and help each other and meet "mid" or "high" category (this is taken from observation checklist).

2. Implementation of Action Plan

The implementation was actually the manifestation what had been designed in the lesson plan. The researcher and her collaborator conducted the treatment in the classroom based on the lesson plan. To do it well, she used appropriate and interesting material and media, and focused on teaching vocabulary through alphabetical cards.

In this study, the collaborator acted as an observer towards the activities that is conducted in the classroom. While, the researcher is the one who conducted the treatment to the students. She was asked to observe the implementation of the technique.

\section{Observation}

In this step, the collaborator observed the way the researcher implemented alphabetical cards technique. The researcher also analyzed the students' achievement in vocabulary mastery. During the teaching and learning process, the 
researcher controlled, guided and identified students' problem. All these activities were observed by the researcher and her collaborator.

\section{Kinds and Source of the Data}

Kinds of the data that were collected in this research were going to be qualitative and quantitative ones. In this study, the qualitative data were taken from (1) researcher's teaching performance, (2) students' classroom participation. It meant that the data related to the ongoing teaching and learning process and researcher's preparation. Meanwhile, the quantitative data were taken from the students' achievement in vocabulary after they have completed the test (Marzuki, 2019b).

\section{Instruments and Procedures of Data Collection}

The researcher employed some instruments that comprised observation checklist, field notes, questionnaire and test. Those instruments were applied in the following procedures.

First, observation checklist was prepared. It is used to identify and to obtain data on students' classroom performance and researcher's teaching performance. The students' classroom performance covered students' response toward the teaching learning process, problems they encountered when doing the classroom task. Observation checklist that was provided to gain data related to researcher's performance was aimed at evaluating the way the researcher provided modeling to students, the researcher controlled and guided the students on task, and the way the researcher provided students' with evaluation.

Second, Field notes. Field notes were one of the research instruments that were applied to obtain data from the field. It covered all information about the researcher activities in doing the research. Field notes were used to record broad events during the observation activities. This research employed field notes mainly to collect data on implementation of classroom teaching vocabulary.

Third, this instrument was used to gather information or data about students' opinion, progress and teaching strategy or material preparation, and technique used. The questionnaire consisted of ten anonymous questions. The students did not need to write their names on the questionnaire forms. 
Finally, the test was designed to measure student's achievement in vocabulary. Kinds of vocabulary test that were employed in this research contain the questions related to the vocabulary. The tests were administered at last meeting of the cycle.

\section{Technique of Data Analysis}

To analyze the data, the researcher used qualitative and quantitative analysis. Each of items was analyzed based on the fact in the field.

Qualitative data were taken from; first, the result of observation related to researcher's performance based on the criteria of teaching procedure designed. The criteria of the categorizing researchers' performance were in form of "Yes" if the procedure was implemented, and "No" if the procedure was not implemented. The categorizing of researcher's performance was then determined "Successful" if indicator was "Yes" and "Failed" if indicator was "No". Second, the result of students' classroom participation was analyzed through 'Low, Mid, and High.

The quantitative data were analyzed from students' final achievement. It was taken from the result of the test that researcher administered at the end of each cycle. The test consisted of twenty items and each item had 1 point. Therefore, the maximum point was 20. The researcher and the collaborator analyzed the students' score data by using this formula adapted from Sutomo (1985: 123) as follows:

Achievement point

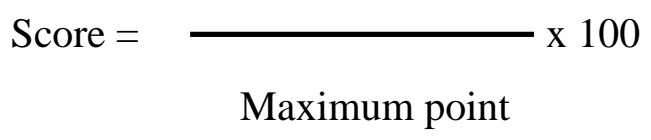

Then, the data obtained from the test were analyzed to measure their achievement whether they were successful or not. The following table illustrates the point.

Figure 2: Level of success 


\begin{tabular}{|c|c|c|c|}
\hline Score & Qualification & Level of Success & Criteria \\
\hline $81-100$ & Very good & Successful & Very effective \\
$65-80$ & Good & Successful & Effective \\
$41-64$ & Fair & Failed & Less effective \\
$1-40$ & Low & Failed & Not effective \\
& & & \\
\hline
\end{tabular}

(Adapted from Harris, 1969: 35)

To know the students' success in increasing the vocabulary, the researcher used the following formula as proposed by Harahap, 1992: 187):

$$
\text { Successful Percentage }=\frac{\text { Total successful students }}{\text { Total students joint the test }} \times 100 \%
$$

\section{Discussion}

\section{Research Results}

The discussion is on the basis of findings presented in this chapter. The researcher initialized the discussion with the preparation she did before conducting the research. The preparation was done with respect to the research need. It comprised research instrument in which the researcher used them in gathering data from the field.

To prepare those instruments are important to do in order to make the research well-prepared. Corresponding to the above task, the researcher and the collaborator worked together preparing researcher instrument, instructional materials and media as well. The researcher provided some instructional materials and media which were necessary for teaching. Meanwhile, the collaborator multiplied observation checklist, he used to observe the teacher's performance and students' response during the teaching process; and other instrument such as evaluation sheet and field notes. There were four main preparations the researcher and her collaborator before they did the action. The preparations corresponded to research instruments, in which they comprise observation checklist, questionnaire, 
field notes, and test. Moreover, to conduct a smooth teaching learning process, the researcher also prepared teaching materials and teaching aids she employed in the teaching learning process.

a. Research Instruments

Research instruments were valuable to gain reliable data that was important for the researcher to analyze them. There are two advantages of preparing research instruments before the researcher conducted the research; the accomplishment of reliability and validity of the instruments themselves; and the reliability and the validity of the data.

Well-prepared research instruments lead the researcher to construct validity and reliability of them. It is considered important for the need of the researcher. Meanwhile, suitable instruments will highly determine the reliability and validity of the data. In references to the preparation on research instruments, the researcher considered that she has the established appropriate researcher instrument on the basis on research need. Moreover the research instrument she utilized to collect data in accordance to the characteristic of the data. It means that the researcher has prepared appropriate researcher instruments before she and the collaborator were in action doing the research. She provided research instruments with kinds of the data he need to gain.

b. Instructional Material and Media

The preparation on instructional material and media was important to be done before the research was conducted. Preparation was closely related to teaching planning. Based on the findings, there were five items the researcher prepared or planned in relation to instructional materials and media. They consisted of lesson plan, teaching materials, teaching media, evaluation sheet, and scoring sheet.

The findings concerning with instructional preparation or planning that were presented in this chapter showed that what the researcher had done some important preparations before he came to the field of research. She really understood what should she did to make the researcher well-prepared and well- 
organized. The actions that the researcher did in preparing instructional materials and media were considered as one of the consequences in doing teaching activity.

2. Planning for the First Cycle

The initial task for the researcher to do when she wanted to begin the teaching learning process of the first cycle was to prepare lesson plan. Lesson plan contained time allocation, standard competence and basic competence, indicator for students' achievement in vocabulary class, teaching objectives, teaching materials, teaching method, teaching procedures used by the researcher, teaching resources, and evaluation. To do the prepare lesson plan for teaching is a must for a teacher before she conducts teaching learning process.

It is understandable that well-prepared lesson plan will contribute a sense of confidence for the teacher to teach. The teacher will feel secured from losing direction in the middle of the lesson if he previously organized lesson plan well. So, in response to the findings, the researcher developed a model of lesson plan that can provide him with guaranty for satisfactory teaching and for attaining instructional objectives.

Other components of lesson plan that the researcher should also consider to prepare were indicator and instructional objectives. Instructional objectives were necessary to be constructed by the researcher since they have sense of direction to lead the researcher and the students to achieve expected teaching learning objectives. Each lesson will have one or more objectives. An objective is the statement of intended learning outcomes. Objectives commonly describe what the students will be able to do when instruction has been completed. In line with the statement, the researcher constructed instruction objectives in respect to the language skill in which the students have to reach at the end of the lesson. Since the research emphasized on teaching vocabulary; so she specified instructional objectives on the area of the intended skill. Specifying instructional objectives means constructing a framework of instruction and focusing it to specific target of learning.

Instructional objectives should be explicitly stated in lesson plan to enable the teacher to control her teaching learning process to be in right path. What the 
researcher has done in her lesson plan was she explicitly stated instructional objectives and limited them on the basis of language skill that she needed to improve. Moreover, instructional objectives should be in line with the topic that the students are going to study. In the first cycle, the researcher served the students with the topic about "things in the classroom and school environments". In this matter, the researcher needed to include one of instructional objectives dealing with topic. So it is reasonable that instructional objectives should also be related to the topic.

In order to provide an accurate judgment about the successfulness of the teaching learning process, the researcher needed to construct indicators of achievement. Indicators must be with respect to instructional objectives, and must be in a harmony with basic competence and standard competence. The indicators of teaching learning achievement are useful to observe whether or not the instructional has been achieved. From the findings, it was found that the researcher arranged indicators of achievement by limiting them only in the area of teaching vocabulary. Similar to instructional objectives, indicators of achievement was also arranged in accordance with the topic of the lesson. The expected teaching objectives that the researcher constructed in the lesson plan in the first meeting were as follows:

By the end of the class, the students are able to:

a. Arrange the letters become a word.

b. Mention several words related to the things in the classroom and school environments.

c. Complete the missing letters of the words.

3. Student's Participation in Teaching Learning Process

Assessment on teaching learning process should be holistically conducted by the researcher in order to enable the teacher to administer an accurate judgment about the process. Holistic assessment includes the assessment concerns about students' participation in classroom interaction. Students' participation need to be assessed to make sure that they are appreciated every time they do their best. In conjunction to assessment on students' participation, students' participation in the 
teaching learning process can be assessed by using provided charts. It is clear that to assess or to evaluate students' participation contributes to reduce their anxiety to lesson or any quite complicated classroom task. To assess students' classroom participation, the researcher employed observation checklist that contains five observed items: enthusiasm, motivation, interest, response, and progress. Those items were observed and assessed by the collaborator.

\section{Student's Performance in Teaching Learning Process}

Students' performance in the teaching learning process was represented by five components in which the students were assessed. It was by purpose prepared by the researcher in order to see the difference in students' performance from meeting to meeting. It is clear that to assess or to evaluate students' performance contributes to reducing their anxiety to lesson or any quite complicated classroom task.

The components that the researcher used them as indicators to assess students' performance in the teaching learning process are student's enthusiasm, motivation, interest, response, and students' progress. The five components were carefully observed to make sure that the students have progress in classroom performance from one meeting to other meeting.

The result of the analysis toward students' classroom performance is going to be explained as follows: (1) Students' enthusiasm toward the teaching learning process in (a) most of the student in meeting 1 and 2 cycle I were in middle category; (b) most of the student in meeting 3 cycle I were in high category, (c) meeting 1, 2, and 3 cycle II were in high category. From the data presentation, it can be concluded that the students have an improvement in terms of their enthusiasm when they were in the second meeting; and they could stand on the improvement up to meeting 3. It is because of the researcher's treatment where she explained the task or gave instruction using English, the teacher needed to explain it in Indonesian to prevent to students misunderstanding the information given.

(2) The analysis on students' motivation shows that (a) meeting 1, 2, and 3 cycle I were in middle category; (b) meeting 1 and 3 cycle II were in middle 
category; (c) meeting 2 cycle II were in high category. From the description, it can be interpreted that the students were motivated to join the class. They competed to get teacher's attention in order to be provided with task to complete. (3) The finding concerns with student's interest explains that meeting (a) 1, 2, and 3 cycle I were in middle category; (b) meeting 1,2, and 3, cycle II were in high category. The findings related to students' interest throughout classroom meetings expose a difference. If the students were in the middle category regarding to their interest in the first cycle; it is different from the second cycle. Since the researcher found that there was any significant progress in interest when they were in the second cycle. (4) Students' response toward the teaching learning process was one of the components that the researcher observed during teaching learning process. The result of observation shows that (a) meeting 1 cycle I is in low category; (b) meeting 2, and 3 cycle I were in middle category; (c) meeting 1 and 2 cycle II were in middle category; and (d) meeting 3 cycle II were in high category. It seemed that the students did not have any spontaneous response toward teacher's instruction, given lesson until they were in the second meeting of cycle I. They achieved high category concerning to response when they were at meeting 3 cycle II. The researcher views that this kind of progress is categorized indolent. (5) It was found that student's progress changed from meeting to meeting; meeting 1 cycle I is in low category; (b) meeting 2 and 3 cycle I were in middle category; (c) meeting 1 and 2 cycle II were in middle category; and (d) meeting 3 cycle II were in high category. From the description above, the result of analysis can be concluded that the students attained the pick of progress when they were in the second meeting of cycle I. It is because of the researcher's treatment on giving more chance to the students for asking clarification when they still do not understand yet about the task.

\section{Students improvement}

The students' improvement in vocabulary through alphabetical cards were investigated and analyzed through evaluation phase of the teaching learning process. The researcher focused on the three criteria of success in which she 
needed to analyze at the end of cycle. In order to provide better understanding toward the findings, the result of analysis is going to be elaborated as follows:

a. Meetings 1, 2, and 3, in cycle I

To analyze the three criteria of success, the researcher utilized alphabetical cards, observation check-list, and field notes. The result of analysis was that from the first test of the cycle 1 it was found there were ten of thirty five students who got "good" score and four students who got "very good" score. It meant that the students' successful percentage that got success level from the first test of cycle I had not yet meet the criteria of success. Because, the percentage approach employed formula 18x100\%:405 = 45\%. 18 was the number of students who got success qualification; 40 was the number of all students, and 100 is the deviation scale. On the other hand, the percentage of classroom success should be $70 \%$ of the number of students.

Meanwhile, the score of fourteen students were more than 70. It was not representative enough for the researcher to judge that the criteria of success have been achieved since the criteria of success for individual students should be 70 . Thus, in other words, the researcher argued the criteria of success will be achieved if more than half of students achieve score 70 or over it and there are at least $70 \%$ from total students got success level. Furthermore, individual score however was to judge the students' achievement individually. There are several reasons why the students could not reach the criteria of success in cycle I, namely: the researcher did not explain the instructions until all of the students understand well, even she gave chance to the students for asking clarification but the chance was not cover all students who needed the clarification.

The students' participation in learning process was identified through classroom activities. Participation as a form of learning process was analyzed qualitatively. The result of observation shows that the students were actively participating in classroom activities.

b. Meetings 1, 2, and 3 in cycle 2

The result of analysis toward evaluation on cycle II meeting 3 evoked the significant development on students' vocabulary. Through the second test in cycle 
II; it was found that there were thirty two students who got "success" qualification. It means that the number of students who got "success" from the second evaluation of cycle II has met the criteria of success; because the percentage approach employs formula $36 \times 100 \%: 40=90 \% .36$ is the number of students who get "success" qualification; 40 is the number of all students, and 100 is the deviation scale. Since the number of students who got "success" qualification more than a half of the total number of students $(90 \%)$, so it is concluded that the criteria of classroom achievement has been achieved.

Meanwhile the higher score of twenty nine students more than 70. It can be interpreted that it is absolutely reasonable for the researcher to judge that the criteria of success have been achieved since the criteria of success for individual students should be 70; moreover there were twenty nine students who got at least 70 so the number has represented all class participants.

There are several reasons why the students could reach the criteria of success in cycle II, namely:

1. The researcher set the time proportionally for each of the activities done.

2. When asking the students for turn, the teacher should not only give a chance to certain students but also others students proportionally.

3. In explaining the task or giving instruction using English, the teacher explained it in Indonesian to prevent to students misunderstanding the information given.

\section{CONCLUSIONS}

Based on the result of this classroom action research, the researcher concluded as follows: By implementing the alphabetical cards technique, the students were not difficulty to remember vocabulary given. We could see in the first test, the students' improvement reached $45 \%$ of 18 students. Meanwhile, in the second test, students' improvement attained $90 \%$ of 36 students. The teaching-learning activities that were employed in this technique were able to develop student' enthusiasm, motivation, interest, response, and progress in joining the class. 


\section{REFERENCES}

Albana, H. H., Marzuki, A. G., Alek, A., \& Hidayat, D. N. (2020). Cohesive Devices in Student's Writing (A Discourse Analysis on Argumentative Text). Jurnal Pendidikan Humaniora, 8(1), 6-11.

Alek, A., Marzuki, A. G., Farkhan, M., \& Deni, R. (2020). Self-Assessment in Exploring EFL Students' Speaking Skill. Al-Ta lim Journal, 27(2), 208-214.

Alek, A., Marzuki, A. G., Farkhan, M., Surahman, D., Daryanto, D., \& Febrianto, S. (2020). Computer Based Testing in Senior High School on National Examination. Indonesian Journal of Learning Education and Counseling, 2(2), 204-210.

Bailey, K.M. 2005. New Ways in Teaching Speaking. Mc Grow Hill, Boston.

Binkeholz, 1999. What is Learning. http://www.umsl.edu./services/ctl/DIED/ destination 2 adult learning/2b learning.html. Retrieved on July 8, 2010.

Burden, P.R. and Byrd, D.M. 1995. Methods for Effective Teaching, Second Edition. Allyin and Bacon, New York.

Cater R. \& McCarthy, M. 1988. Vocabulary and Language Teaching. New York: Longmen. Inc.

Celce. M. and Murcia, 2001. Teaching English as a second or Foreign Language. United States . (Third Edition).

Frazee, B. M and Rudnitski, R., 1995. Integrated Methods: Theory, Classroom Applications, and Field Based Connections. United States. Delmar Publisher.

Harmer, J. 1998. How to Teach English. Cambridge. Pearson Longman

Harris, D. P. 1969. Testing English as Second Language. New York: McGraw Publishing Company.

Kemmis, S. and McTaggart, R. 1988. The Action Research Planer. Australia. Deakin University.

Kuliahana, A., \& Marzuki, A. G. (2020). Repetition Technique in an EFL Speaking Class in Islamic Higher Education in Indonesia. Academic Journal Perspective: Education, Language, and Literature, 8(1), 20-28.

Lang, H. R. and Nunan, D. 2006. Models, Strategies, and Methods for Effective Teaching. United States. Pearson.

Marzuki, A. G. (2019a). The Implementation of SQ3R Method to Develop Students' Reading Skill on Islamic Texts in EFL Class in Indonesia. Register Journal, 12(1), 49-61.

Marzuki, A. G. (2019b). The Roles of School Principal Leadership in Developing English Teachers' Creativities in Palu. Al-Ta lim Journal, 26(3), 267-279.

Marzuki, A. G. (2019c). Utilizing Recorded English Dialogues in Teaching English Word Stress to Islamic Higher Education Students in Indonesia. Jurnal Pendidikan Islam, 5(1), 53-64.

Marzuki, A. G., Alim, N., \& Wekke, I. S. (2018). Improving the reading comprehension through cognitive reading strategies in language class of coastal area in indonesia. In IOP Conference Series: Earth and Environmental Science, 156(1), 012050). IOP Publishing. 
Marzuki, A.G. (2016). Utilizing cooperative learning in islamic college students' classroom, IJEE (Indonesian Journal of English Education), 3(2), 123-139.

Marzuki, A.G. (2017). Developing speaking skill through oral report in an efl class in indonesia, Al-Ta'lim Journal, 24(3), 243-254.

McNiff, J. 1992. Action Research: Principle and Practice. New York. Chapman and Halls.

Nation, P. 1990. Teaching and Learning Vocabulary. Boston, Massachusetts: Heinle \& Heile Publishers. A division of Wadsworth, Inc.

Nunan, D. 1998. Research Methods in Language Learning. Cambridge University Press, Cambridge.

Richard, J. and Renandya, A. 2002. Methodology in Language Teaching. Cambridge University Press, Cambridge.

Richards, J. 2001. Curriculum Development in Language Teaching. New York. Cambridge University Press.

Rolando, M. 2003. Teaching your Kids through Alphabet Cards. (Online) http://www.reading-with kids.com/Alphabet Cards.html, accessed on April $2,2011$.

Schindler, A. 2006. English Teaching Forum, Channeling Children's Energy through Vocabulary Activities. United States. Canada.

Wallace, M. 1987. Teaching Vocabulary. Heinemann Educational Books, London.

Wallace, M. 1998. Action Research for Language Teachers. Cambridge University Press, Cambridge. 